\title{
Implementation of Ergonomics on Children's Playroom Furniture in Rancamanyar Cluster-Bandung
}

\author{
Tita Cardiah ${ }^{1}$, Hendi Anwar ${ }^{2}$, Andreas Dwiputro Handoyo ${ }^{3}$, \\ ${ }^{1}$ Interior Design Study Program, School of Creative Industries, Telkom University, Indonesia \\ ${ }^{1}$ titacardiah@telkomuniversity.ac.id, 2hendianwar333@gmail.com, \\ 3`ashandoyo@telkomuniversity.ac.id
}

\begin{abstract}
Playroom in a settlement is a form of service to the community local to support all activities related to daily life, especially for social activities, communication, interaction, recreation and education. Improving the quality of citizen services must be supported by appropriate facilities (well organized) expected to be able to provide a positive element in the whole community for local residents, especially in the Rancamanyar Cluster residential neighborhood. Arrangement of playroom facilities can be through good planning and design, so that facilities can function with maximum use to socialize, interact and play comfortably.There are two stages of this research method: planning and development the Rancamanyar cluster desperately needs playroom facilities with ergonomic furniture to fit the children's anthropometry. The playroom is expected to be able to materialize according to the needs of citizens, especially children, so that the playing space is able to increase solidarity, togetherness, kinship and security of citizens and the environment. This condition greatly affects the balance and level of service of citizens, especially children, both socially and individually. Ergonomic implementation of children's playroom furniture in Rancamanyar Cluster is a solution to resolve the above problems.
\end{abstract}

Keywords: ergonomics, children's playroom, furniture

\section{INTRODUCTION}

Housing and settlement is a form of environment that requires a variety of facilities both public and social facilities.Social facilities needed for residents are facilities in the form of furniture that can accommodate daily activities that are socializing, communication, interaction, recreation and education. Definition of the design brief and its objectives should enable the design team to establish the general proposition of a design. The proposition can be used to describe the general ideas and values that a design intends to present to, and be internalised by, the target audience [1].

True search is active and causes the intervention of movements which do not solely extend the interrupted action, whereas in the present behavior patterns either there is simple expectation, or else the search only continues the earlier act of accommodation [2].Facilities and infrastructure as well as facilities Housing and settlements will affect the level of togetherness, health, personality and welfare of local residents, especially for children.Bodily/Kinesthetic Intelligence is the ability to use the body to express ideas feelings and to solve problems. Interpersonal Intelligence refers to the ability to understand another person "s feelings, motivations, and intentions; people with this intelligence work more effectively in teams and social settings [3]. Positive discovery of the relationship between child's level of motor skills and cognitive abilities would support the idea of early 
childhood intervention by ducators in the youngest age groups, where these interventions can be highly effective [4].

\section{METHOD}

The design / design process. Arrangement of playroom furniture in Rancamannyar settlement with amphitheater design and construction output. After surveying and extracting data, the design process is carried out by involving citizens in making corrections to the design output process that residents can use in self-help development.

Design Development. This design covers the various needs of residents in the Rancamanyar settlement, especially as an area of interaction and socialization for children. This park is dominated by green areas so that the design can hold rain water, reduce the impact of heat and also provide space for mothers / residents to beautify with plants

\section{RESULT AND DISCUSSION}

The research stage reviews information such as the history of the design problem, end-user research and opinion-led interviews, and identifies potential obstacles [1]. Development of the design and arrangement of playroom furniture and application of public space standards for social facilities is carried out with due regard to the age of the user, because all citizens have the same right to be able to use public facilities in Rancamanyar housing. Actually the arrangement of this furniture is based on patterns and the flow of service activities (service activity) and circulation in public spaces.

The basis is programming identification, so the problems that arise are problems that cause citizens inconvenience based on the needs of both anthropometry and ergonomics of the space needed. Information is a basic element in programming. Facts and ideas, conditions and decisions, statistics and estimates - all these and many more constitute the information needs [6]. Considering the need for social service facilities related to the suitability between age and service activities in space, the problem is more focused on the problems of applying anthropometry standards and furniture ergonomics based on adjustments between the needs of the service flow with the zoning layout and blocking in the space in accordance with anthropometry standards and ergonomics, functions, flow of activities, and aesthetics.

The arrangement of playroom furniture for children especially in open spaces must pay attention to security, comfort and of course sustainability. Sustainability means the selection of materials that must be durable and weather resistant because they will be exposed to sunlight or rain all day. To develop furniture design and arrangement, the application of ergonomic standards for children is the main thing that becomes the design concept, it takes into account the age of the user, where in the Rancamanyar settlement the age of children varies greatly from toddlers to 15 years old. This is important because all citizens have the same right to be able to use this playground in Rancamanyar housing, so that comfort, togetherness, family and security can be created between residents and their environment. Based on the problems mentioned above, then some solutions that can be done are:

1) This playroom furniture arrangement solution is based on user, pattern and flow of activities, services (service activity) and circulation in the play area. Considering the importance of playroom facilities related to the suitability between age and service activities in space, the solution is more focused on solving the problems of applying anthropometry standards and ergonomics of furniture that are child friendly and environmentally friendly. This section also involves feedback and feedforward of information as well as covers the processing of data into information [6]. To accommodate these activities, a safe and comfortable playroom is needed.In this respect the present behavior patterns merely extend those of the second stage but reveal essential progress: the child no longer seeks the object only where he has recently seen it but hunts for it in a new place [2]. 
2) These playroom facilities must be able to accommodate the needs of children, such as recreational facilities, education and outreach. Recreation, means that this interested space is a fun place to play with children of their own age and with older and younger children of their age. Recreational facilities are provided in the form of traditional Sundanese games, sondah, so that children are familiar with traditional games. Education, means that this playroom is not just playing but is able to educate children through reading facilities, the amphitheater area as a shared learning space.Children are the valuable social capital and build the society future. Education in childhood, the time of the formation of personality and creation of different habits, establishes the future of the individual and the society [5]. Socialization, means that this playroom is able to create solidarity, togetherness, tolerance and knowing the outside world for children so they don't get bored playing inside the house.

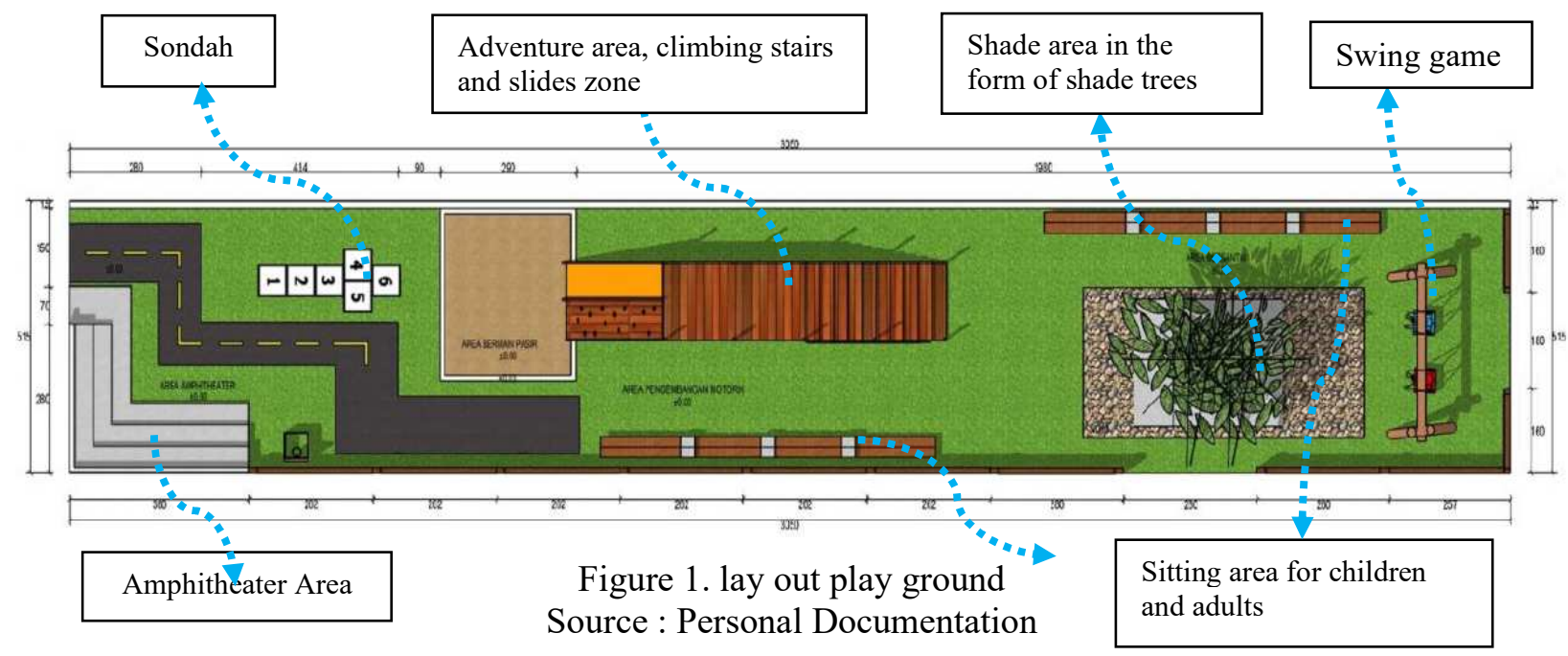

We have as an overall objective, the creation of more suitable furniture for children, leading to extended product life cycles and contributing to sustainable development. Namely, through the design of a chair which can follow child's growth from 6 months up to 7 years old and guarantees physical and visual comfort, without being overpriced nor "disposable".[9]. This area is designed in such a way that the development process can be carried out in stages with community self-help funds as well. The design is divided into several main parts that can be built in stages, namely:

\section{Amphitheater Area}

This area can be used by children to sit and relax and play which can practice basic motor movements. Children can go up and down, walk or sit on it. The shape resembles the letter L, so that children can watch or adults to sit while watching their children who are playing. This area is equipped with toys and trash facilities that are designed to be more interactive with residents / children by adding a basketball board. 

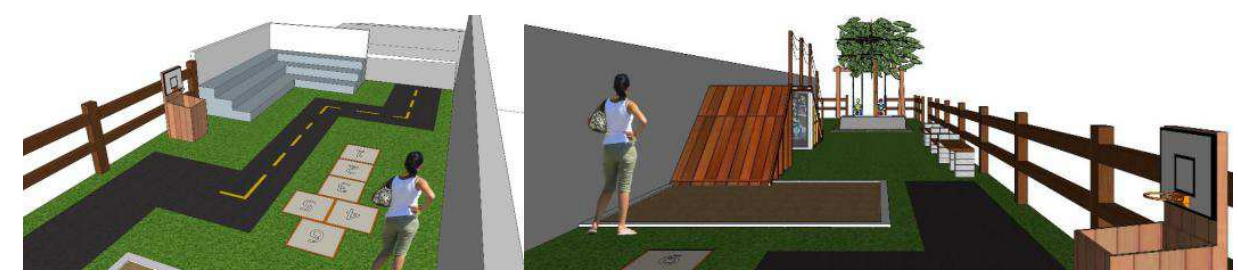

Figure 2 Amphiteater Area and Adventure area, climbing stairs and slides Source : Personal Documentation

In addition to these areas, there are compact game tools that not only function as entertainment games, but are also equipped with educational facilities. These behavior patterns are important; their accumulation and systematization will gradually bring with them belief in the permanence of the external world. But they are not in themselves alone enough to constitute object concept. They imply simply that the child considers as permanent everything which is useful to his action in a particular situation under consideration [2]

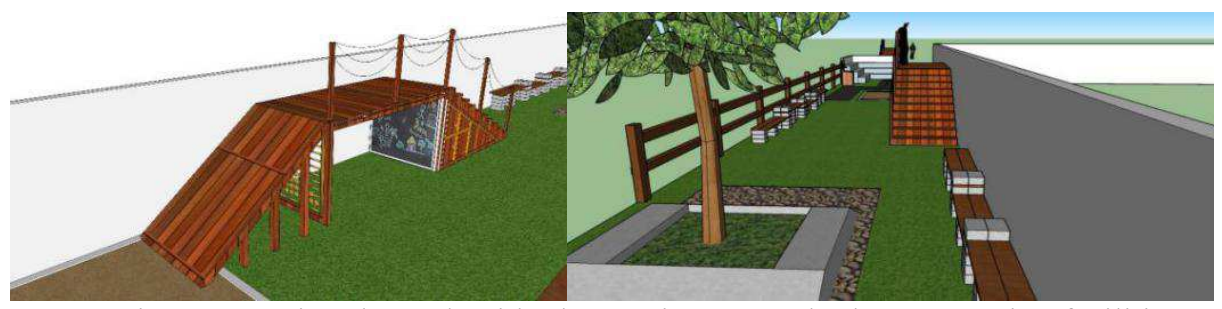

Figure3. Design the park with play equipment and other supporting facilities Source : Self Documentation

\section{Swing game area}

At the other end, the open space is equipped with a swing game, with vegetation and a sitting area for parents who accompany their children. Overall, the garden design is designed with the use of various materials that can also be used to educate children more familiar with their environment.
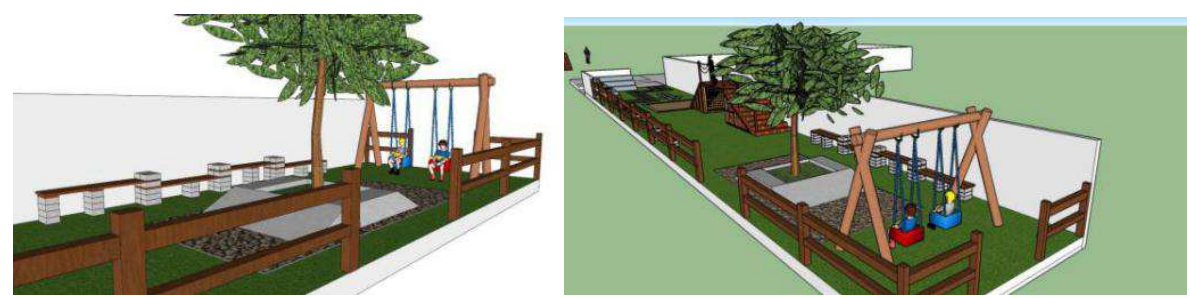

Figure4.Design the park with play equipment and other supporting facilities Source : Self Documentation 


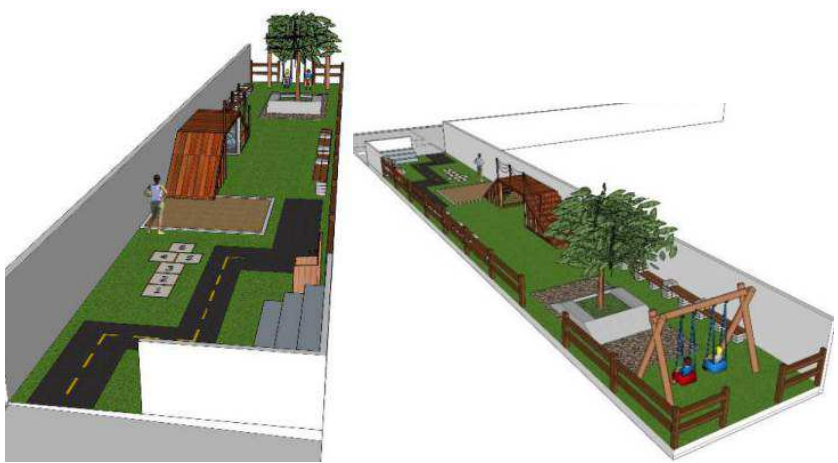

Figure 5. Aerial Perspective of Garden Design in Rancamanyar Settlement Source : Self Documentation

\section{Implementation Phase}

Amphitheater area is very much needed because there are many activities that residents can do in this area, especially children, such as gathering, reading, eating together, and other games. Implementation is the end of the design process and involves physically putting into effect many of the design decisions previously taken, such as those regarding format, scale, media and use of materials [1].

Following is the construction process for the construction of the Amphitheater Area:

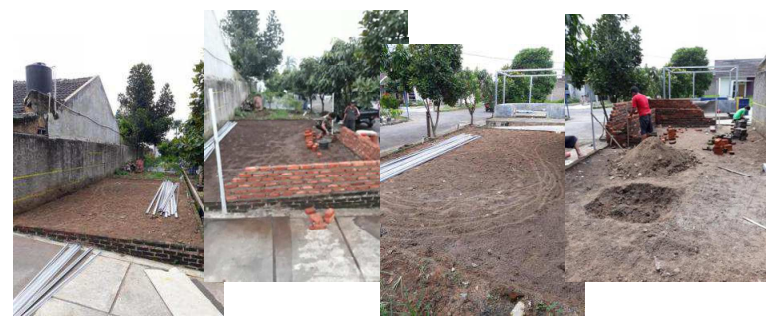

Figure 6. land maturation and constructiin Source : Self Documentation

When it comes to designing a product, human factors and ergonomic studies frequently focus on function and utility issues. Besides anthropometric data, physiological research and all the functional aspects of human activity, to search what kind of features can make a bigger emotional attachment to a certain object is an important step for an optimized design project (Jordan, 1998)Leading an investigation aimed to design children's domestic furniture, focusing in the child's wellbeing and the surrounding environment, it seemed necessary to explore issues related with the child's emotional and sensitive satisfaction when using a product [7]. 


\section{CONCLUSION}

Playroom facilities in this settlement, can function as a playground, gather, study, and socialize all children and adults in the Rancamanyar cluster. This facility can accommodate the needs of residents of Rancamanyar settlement for interaction facilities, gathering points, including routine activities such as when August events, Post Yandu activities and weekend activities. The response obtained from presentations to residents, they are interested in using this playroom facilities for various future residents' activities especially children. In the next stage, residents expect control and supervision assistance at the development and realization stages. As for the residents' request to continue with similar programs for other public facilities. Assistance from academics through the abdimas program was felt to be very helpful and could be continued to co-exist with the results of community self-help..

\section{REFERENCES}

[1] G. Ambrose, Paul Harris, Basic Design -design Thinking, Published by AVA Publishing SA, AVA Publishing SA AVA Book Production Pte. Ltd., Singapore, 2010,

[2] J. P IA G E T, The Construction Of Reality In The Child, Founded by C. K. Ogden, by Routledge 2 Park Square, Milton Park, Abingdon, Oxon, 0X14 4RN,2000,

[3] M. Ouchen Dr, Reflection On Multiple Intelligences Theory As A Framework For Elt: Meeting Esp Learners' Specific Needs, The National Library, The Kingdom of Morocco, IJAEDU- International E-Journal of Advances in Education, Vol. V, Issue 14, August, 2019

[4] L. Miklánková Assoc. Prof,,Cognitive Competence Of A Child In Primary School Age In The Context Of Gross Motor Skills.Department of Primary and Pre-primary Education, Palacký University in Olomouc, Czech Republic, Ijaedu- International E-Journal of Advances in Education, Vol. V, Issue 14, August, 2019.

[5] A.Farahani P, Mokhtarinia H, Osqueizadeh R, Design of an Ergonomics Assessment Tool for Playroom of Preschool Children, , Physical Treatments - Specific Physical Therapy, vol. 6, issue 4 pp. 217-226 Published by CASRP: Center of Advanced Scientific Research and Publications. 2017.

[6] M.William Peña Steven A. Parshall, Problem Seekingтм is a registered trademark owned by HOK Group, Inc. Published by John Wiley \& Sons, Inc., New York 2001

[7] S. Kubba, Spacae Planning For Commercialland Residential Interior, McGRAW-HILL

[8] A. David LauerStephen Pentak, Basic Design, Seventh Edition, The Ohio State UniversityThomson Wadsworth, a part of The ThomsonCorporation.2008

[9] C. Salvador, José Vicente and João Paulo Martins, Ergonomics in Children's Furniture - Emotional Attachment, Proceedings of the 5th International Conference on Applied Human Factors and Ergonomics AHFE 2014, Kraków, Poland 19-23 July 2014

[10] K. Widyawati, Laksmitasari R. Penilaian Ruang Bermain Anak di Kota Depok Sebagai Salah Satu Indikator Tercapainya Kota Layak Anak. Faktor Exacta. 2015 Oct 8;8(3):165-207.

[11] A.O. Diyanti , Amiuza CB, Mustikawati T. Lingkungan Ramah Anak pada Sekolah Taman Kanak-Kanak. RUAS (Review of Urbanism and Architectural Studies). 2015 Feb 12;12(2):54-68

[12] J. Hasimjaya, Wibowo M, Dodi Wondo, Kajian Antropometri \& Ergonomi Desain Mebel Pendidikan Anak Usia Dini 3-4 Tahun di Siwalankerto, Jurnal Intra, vol. 5, issue 2 (2017) pp. 449-459 
[13] L. Purwaningrum, Funatsu K, Xiong J, Rosyidi C, Muraki S, Effect of furniture weight on carrying, lifting, and turning of chairs and desks among elementary school children, PLoS ONE, vol. 10, issue 6 (2015) Published by Public Library of Science

[14] A. Holis, Belajar Melalui Bermain untuk Pengembangan Kreativitas dan Kognitif Anak Usia DiniJurnal Pendidikan, vol. 10, issue 1 (2015) pp. 23-37 